Article

\title{
Laminariales Host Does Impact Lipid Temperature Trajectories of the Fungal Endophyte Paradendryphiella salina (Sutherland.)
}

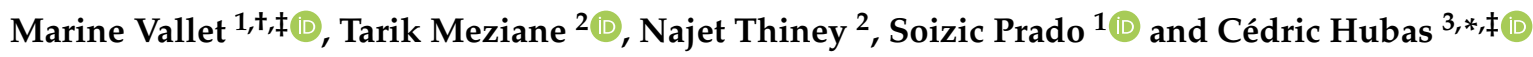 \\ 1 Molécules de Comunications et Adaptation des Microorganismes (MCAM) Muséum National d'Histoire \\ Naturelle, CNRS, 63 Rue Buffon, FR-75005 Paris, France; mvallet@ice.mpg.de (M.V.); \\ soizic.prado@mnhn.fr (S.P.) \\ 2 Laboratoire de Biologie des Organismes et Ecosystèmes Aquatiques (BOREA), Muséum National d'Histoire \\ Naturelle, IRD, SU, CNRS, UA, UCN, 61 Rue Buffon, FR-75005 Paris, France; tarik.meziane@mnhn.fr (T.M.); \\ najet.thiney@mnhn.fr (N.T.) \\ 3 Laboratoire de Biologie des Organismes et Ecosystèmes Aquatiques (BOREA), Muséum National d'Histoire \\ Naturelle, IRD, SU, CNRS, UA, UCN, Station Marine de Concarneau, FR-29900 Concarneau, France \\ * Correspondence: cedric.hubas@mnhn.fr \\ † Current address: Max Planck Fellow group Phytoplankton Community Interactions, Max Planck Institute \\ for Chemical Ecology, Hans-Knöll-Straße 8, D-07745 Jena, Germany. \\ $\ddagger$ These authors contributed equally to this work.
}

Received: 4 June 2020; Accepted: 13 July 2020; Published: 22 July 2020

\begin{abstract}
Kelps are colonized by a wide range of microbial symbionts. Among them, endophytic fungi remain poorly studied, but recent studies evidenced yet their high diversity and their central role in algal defense against various pathogens. Thus, studying the metabolic expressions of kelp endophytes under different conditions is important to have a better understanding of their impacts on host performance. In this context, fatty acid composition is essential to a given algae fitness and of interest to food web studies either to measure its nutritional quality or to infer about its contribution to consumers diets. In the present study, Paradendryphiella salina, a fungal endophyte was isolated from Saccharina latissima (L.) and Laminaria digitata (Hudson.) and its fatty acid composition was assessed at increasing salinity and temperature conditions. Results showed that fungal composition in terms of fatty acids displayed algal-dependent trajectories in response to temperature increase. This highlights that C18 unsaturated fatty acids are key components in the host-dependant acclimation of P. salina to salinity and temperature changes.
\end{abstract}

Keywords: fatty acids; fungal endophytes; laminariales; Paradendryphiella salina

\section{Introduction}

Kelps are colonized at their surface, but also within their tissues, by a wide range of micro-organisms and thus act as hosts to species-rich assemblages of algae, animals and microbes. The associated microorganisms are responsible for spreading infectious algal diseases, protecting against fouling organisms and pathogens or producing substances that promote algal growth [1]. Among these micro-organisms, endophytic fungi remain poorly documented although recent studies evidenced their high diversity [2] and their key role in algal defence against various pathogens. Their role is still virtually unknown and there is a need to examine how environmental factors influence the relationship between the fungi and their hosts [1].

In that context, isolation of P. salina (Ascomycota) strains from several brown algal species has brought new insights into the complex relationships between these macroalgae and their microbiote. 
The observed association of the fungus to brown algae dates back to 1916 when it was first described as Cercospora salina [3]. Its ecological mode and habitat were described as saprophytic on seaweeds. It is extremely widespread and has then been found in many ecosystems from the tropics to mid latitudes. It occurs in salt marshes, in sediments, at the surface of living or dead algae thalli [4], sea grasses and woods and has been successfully, isolated from various plant and algal substrates at different geographical locations and climatic zones ([5,6] and references therein).

This fungus was studied for its adaptations to the abiotic and biotic parameters commonly found in its natural marine habitats. All the tested strains grew optimally on culture media with added marine salts, at $\mathrm{pH}$ values between 6.5 and 8.0 and at an incubation temperature of $25^{\circ} \mathrm{C}$. It generally exhibits an increased salt optimum with increasing incubation temperature and clearly demonstrate an important phenotypic plasticity and the ability to adapt to diverse biotopes [5]. Recent studies have demonstrated that this common fungal endophyte produce bioactive pyrenocines and pyrenochaceatic acid which may confer protection to the host algae against pathogen infection [2]. Furthermore, bacterial and fungal endophytes associated to four brown algae Ascophyllum nodosum (L.), Pelvetia canaliculata (L.) L. digitata, and S. latissima produce metabolites that interfere with bacterial autoinducer-2 quorum sensing (QS), a signalling system involved in virulence and host colonization [7]. Recent results suggest that QS quenching may be linked to a novel $\alpha$-hydroxy $\gamma$-butenolides produced by P. salina which interfere with the QS system of the pathogenic bacterial model Pseudomonas aeruginosa (Schroeter.) [8]. In addition, a recent study reveals the ability of $P$. salina to degrade alginate of brown algae [9].

Kelps are particularly rich in palmitic acid (16:0), palmitoleic acid (16:1n-7), oleic acid (18:1n-9), linoleic acid (18:2n-6) and arachidonic acid (20:4n-6) but composition may vary according to environmental factors especially temperature and depth [10,11]. A tendency of decreasing unsaturation towards the warmer seasons has been observed and the comparison of fatty acid profiles between S. latissima (L.), Saccorhiza polyschides (Lightfoot.), and Laminaria ochroleuca (Bachelot de la Pylaie.), also indicated species-specific factors [10]. In light of recent evidences of the hitherto unsuspected diversity of fungal endophytes in brown algae, it is not clear whether algal or fungal cells are responsible for previously observed changes in fatty acids composition of kelps (especially in palmitic acid together with oleic, linoleic and linolenic acids 18:3n-3) according to environmental conditions and/or species-specific factors. Most fungi are indeed very rich in C18 fatty acids [12].

These metabolites are important structural components, but also active constituents in several physiological processes. For instance, oxylipins which are key signalling molecules in stress response and immunity [13] and have important implication in fungal development and pathogen/host interactions [14] are produced enzymatically or non-enzymatically as a result of oxygenation of C18 fatty acids by free radicals and reactive oxygen species [15]. The aim of the present study was thus to explore fatty acid synthesis of a common kelp endophyte under different conditions to understand the potential role of $P$. salina on its host metabolism.

\section{Results}

\subsection{Fatty Acid Compositions}

Fatty acid compositions of P. salina strains LD40H and SL540T are reported in Table 1. A total of 22 fatty acids were detected. Saturated fatty acids (SFA) were lauric acid (12:0), myristic acid (14:0), pentadecylic acid (15:0), palmitic acid (16:0), margaric acid (17:0), stearic acid (18:0), arachidic acid (20:0), and behenic acid (22:0). Altogether, 16:0 and 18:0 were the most abundant SFA and contributed in average $23 \pm 3$ and $4 \pm 1 \%$ to total fatty acids (TFA), respectively. Mono-unsaturated fatty acids (MUFA) were myristoleic acid (14:1n-5), palmitoleic acid (16:1n-7), hypogeic acid (16:1n-9), 17:1n-7, 17:1n-9, vaccenic acid (18:1n-7), oleic acid (18:1n-9), and 20:1n-9. Across all treatments, $18: 1 n-9$ was the most abundant MUFA ( $28 \pm 4 \%$ of TFA). Measured poly-unsaturated fatty acids (PUFA) were 16:2n-4, 16:2n-6, 17:2n-5, Linoleic acid (18:2n-6), alpha-linolenic acid (18:3n-3), and 20:2n-9. Linoleic acid was the most abundant PUFA as well as the most abundant fatty acid with $40 \pm 3 \%$ of TFA. 
Table 1. Fatty acids concentrations $\left(\mu^{-1} \mathrm{~g}^{-1}\right)$ in the extracts of endophytic P. salina isolated from L. digitata (LD) or S. latissima (SL) and grown at different salinities (S1, S2 and S3 at 23.5, 50 and 70 PSU respectively) and temperatures (T10, T18 and T25 at 10, 18 and $25^{\circ} \mathrm{C}$ respectively). <dl indicates the signal was below detection limit.

\begin{tabular}{|c|c|c|c|c|c|c|c|c|c|c|c|c|c|c|c|c|c|c|}
\hline \multirow[b]{2}{*}{ Host algae } & \multirow[b]{2}{*}{ Temperature } & \multirow[b]{2}{*}{ Salinity } & \multicolumn{2}{|c|}{$12: 0$} & \multicolumn{2}{|c|}{ 14:0 } & \multicolumn{2}{|c|}{$14: 1 n-5$} & \multicolumn{2}{|c|}{$15: 0$} & \multicolumn{2}{|c|}{$16: 0$} & \multicolumn{2}{|c|}{$16: 1 n-7$} & \multicolumn{2}{|c|}{$16: 1 n-9$} & \multicolumn{2}{|c|}{$16: 2 n-4$} \\
\hline & & & mean & sd & mean & sd & mean & sd & mean & $\mathrm{sd}$ & mean & $\mathrm{sd}$ & mean & sd & mean & sd & mean & $\mathrm{sd}$ \\
\hline LD & $\mathrm{T} 10$ & S1 & 0.02 & 0.022 & 0.04 & 0.007 & 0.01 & 0.001 & $<\mathrm{dl}$ & $<\mathrm{dl}$ & 4.79 & 1.069 & 0.16 & 0.035 & 0.03 & 0.005 & 0.01 & 0.003 \\
\hline SL & $\mathrm{T} 10$ & S1 & $<\mathrm{dl}$ & $<\mathrm{dl}$ & 0.03 & 0.005 & $<\mathrm{dl}$ & $<\mathrm{dl}$ & 0.01 & 0.001 & 4.55 & 0.899 & 0.12 & 0.045 & 0.03 & 0.008 & 0.01 & 0.002 \\
\hline LD & $\mathrm{T} 18$ & S1 & 0.01 & 0.010 & 0.03 & 0.011 & 0.01 & 0.000 & 0.01 & 0.002 & 5.2 & 1.472 & 0.25 & 0.044 & 0.04 & 0.008 & 0.02 & 0.004 \\
\hline SL & $\mathrm{T} 18$ & S1 & $<\mathrm{dl}$ & $<\mathrm{dl}$ & 0.02 & 0.003 & $<\mathrm{dl}$ & $<\mathrm{dl}$ & 0.01 & 0.002 & 3.36 & 0.810 & 0.16 & 0.040 & 0.03 & 0.008 & 0.01 & 0.001 \\
\hline LD & $\mathrm{T} 25$ & S1 & 0.01 & 0.005 & 0.03 & 0.004 & 0.02 & 0.015 & 0.02 & 0.005 & 6.24 & 1.586 & 0.46 & 0.126 & 0.06 & 0.016 & 0.03 & 0.009 \\
\hline SL & $\mathrm{T} 25$ & S1 & $<\mathrm{dl}$ & $<\mathrm{dl}$ & 0.03 & 0.005 & 0.01 & 0.003 & 0.01 & 0.003 & 5.26 & 1.311 & 0.34 & 0.081 & 0.04 & 0.008 & 0.02 & 0.004 \\
\hline LD & T10 & S2 & 0.01 & 0.006 & 0.03 & 0.007 & $<\mathrm{dl}$ & $<\mathrm{dl}$ & 0.01 & 0.001 & 3.49 & 0.741 & 0.17 & 0.040 & 0.02 & 0.005 & 0.01 & 0.002 \\
\hline SL & $\mathrm{T} 10$ & S2 & 0.01 & 0.011 & 0.02 & 0.001 & $<\mathrm{dl}$ & $<\mathrm{dl}$ & $<\mathrm{dl}$ & $<\mathrm{dl}$ & 1.87 & 0.640 & 0.1 & 0.044 & 0.01 & 0.005 & $<\mathrm{dl}$ & $<\mathrm{dl}$ \\
\hline LD & T18 & S2 & 0.01 & 0.017 & 0.03 & 0.004 & 0.01 & 0.003 & 0.01 & 0.003 & 3.47 & 1.061 & 0.27 & 0.053 & 0.04 & 0.008 & 0.01 & 0.004 \\
\hline SL & $\mathrm{T} 18$ & S2 & 0.01 & 0.001 & 0.04 & 0.009 & 0.01 & 0.001 & 0.02 & 0.004 & 4.55 & 1.194 & 0.35 & 0.081 & 0.04 & 0.008 & 0.02 & 0.005 \\
\hline LD & $\mathrm{T} 25$ & S2 & 0.01 & 0.002 & 0.08 & 0.030 & 0.02 & 0.010 & 0.02 & 0.005 & 8.5 & 0.643 & 0.94 & 0.088 & 0.09 & 0.008 & 0.07 & 0.004 \\
\hline SL & $\mathrm{T} 25$ & S2 & $<\mathrm{dl}$ & $<\mathrm{dl}$ & 0.09 & 0.031 & 0.02 & 0.003 & 0.03 & 0.007 & 9.8 & 3.034 & 0.95 & 0.230 & 0.08 & 0.014 & 0.05 & 0.014 \\
\hline LD & $\mathrm{T} 10$ & S3 & 0.01 & 0.002 & 0.01 & 0.004 & $<\mathrm{dl}$ & $<\mathrm{dl}$ & $<\mathrm{dl}$ & $<\mathrm{dl}$ & 0.82 & 0.373 & 0.07 & 0.049 & $<\mathrm{dl}$ & $<\mathrm{dl}$ & $<\mathrm{dl}$ & $<\mathrm{dl}$ \\
\hline SL & T10 & S3 & $<\mathrm{dl}$ & $<\mathrm{dl}$ & 0.01 & 0.004 & $<\mathrm{dl}$ & $<\mathrm{dl}$ & $<\mathrm{dl}$ & $<\mathrm{dl}$ & 0.62 & 0.418 & 0.06 & 0.051 & $<\mathrm{dl}$ & $<\mathrm{dl}$ & $<\mathrm{dl}$ & $<\mathrm{dl}$ \\
\hline LD & T18 & S3 & $<\mathrm{dl}$ & $<\mathrm{dl}$ & 0.04 & 0.004 & $<\mathrm{dl}$ & $<\mathrm{dl}$ & 0.01 & 0.001 & 3.6 & 0.277 & 0.38 & 0.037 & 0.01 & 0.003 & 0.02 & 0.002 \\
\hline SL & T18 & S3 & $<\mathrm{dl}$ & $<\mathrm{dl}$ & 0.07 & 0.044 & $<\mathrm{dl}$ & $<\mathrm{dl}$ & 0.02 & 0.013 & 5.91 & 3.655 & 0.76 & 0.493 & 0.03 & 0.020 & 0.03 & 0.017 \\
\hline LD & T25 & S3 & 0.03 & 0.037 & 0.07 & 0.038 & $<\mathrm{dl}$ & $<\mathrm{dl}$ & 0.01 & 0.005 & 5.19 & 4.629 & 0.76 & 0.937 & 0.02 & 0.021 & 0.06 & 0.081 \\
\hline SL & $\mathrm{T} 25$ & S3 & $<\mathrm{dl}$ & $<\mathrm{dl}$ & 0.07 & 0.036 & $<\mathrm{dl}$ & $<\mathrm{dl}$ & 0.02 & 0.008 & 4.87 & 1.677 & 0.78 & 0.383 & 0.03 & 0.008 & 0.04 & 0.022 \\
\hline \multicolumn{2}{|c|}{$16: 2 n-6$} & \multicolumn{2}{|c|}{$17: 0$} & \multicolumn{2}{|c|}{$17: 1 n-7$} & \multicolumn{2}{|c|}{$17: 1 n-9$} & \multicolumn{2}{|c|}{$17: 2 n-5$} & \multicolumn{2}{|c|}{$18: 0$} & \multicolumn{2}{|c|}{$18: 1 n-7$} & \multicolumn{2}{|c|}{$18: 1 n-9$} & & & \\
\hline Host algae & Temperature & Salinity & mean & sd & mean & $\mathrm{sd}$ & mean & sd & mean & $\mathrm{sd}$ & mean & $\mathrm{sd}$ & mean & $\mathrm{sd}$ & mean & $\mathrm{sd}$ & mean & $\mathrm{sd}$ \\
\hline LD & & S1 & 0.01 & $J_{2}$ & & JU0 & 0.01 & 0.0 & $<\mathrm{dl}$ & $<\mathrm{d}$ & $<$ & $<\mathrm{c}$ & 1.31 & 0.291 & 0.1 & 0.015 & 6.6 & 1.774 \\
\hline SL & T10 & S1 & 0.01 & 0.010 & 0.04 & 0.002 & 0.01 & 0.001 & 0.01 & 0.008 & $<\mathrm{dl}$ & $<\mathrm{dl}$ & 1.64 & 0.251 & 0.11 & 0.022 & 5.71 & 1.359 \\
\hline LD & T18 & S1 & 0.02 & 0.003 & 0.03 & 0.006 & $<\mathrm{dl}$ & $<\mathrm{dl}$ & $<\mathrm{dl}$ & $<\mathrm{dl}$ & $<\mathrm{dl}$ & $<\mathrm{dl}$ & 0.97 & 0.363 & 0.17 & 0.090 & 5.34 & 1.333 \\
\hline SL & $\mathrm{T} 18$ & S1 & 0.01 & 0.004 & 0.03 & 0.008 & 0.01 & 0.001 & $<\mathrm{dl}$ & $<\mathrm{dl}$ & $<\mathrm{dl}$ & $<\mathrm{dl}$ & 0.84 & 0.174 & 0.11 & 0.023 & 4.21 & 0.980 \\
\hline LD & $\mathrm{T} 25$ & S1 & 0.04 & 0.014 & 0.04 & 0.016 & 0.01 & 0.002 & $<\mathrm{dl}$ & $<\mathrm{dl}$ & 0.01 & 0.002 & 0.79 & 0.161 & 0.32 & 0.098 & 5.72 & 1.262 \\
\hline SL & $\mathrm{T} 25$ & S1 & 0.02 & 0.004 & 0.03 & 0.007 & 0.01 & 0.001 & $<\mathrm{dl}$ & $<\mathrm{dl}$ & $<\mathrm{dl}$ & $<\mathrm{dl}$ & 0.93 & 0.224 & 0.19 & 0.034 & 6.23 & 1.515 \\
\hline LD & T10 & S2 & $<\mathrm{dl}$ & $<\mathrm{dl}$ & 0.01 & 0.001 & $<\mathrm{dl}$ & $<\mathrm{dl}$ & $<\mathrm{dl}$ & $<\mathrm{dl}$ & $<\mathrm{dl}$ & $<\mathrm{dl}$ & 0.87 & 0.195 & 0.06 & 0.009 & 6.5 & 1.456 \\
\hline SL & T10 & S2 & $<\mathrm{dl}$ & $<\mathrm{dl}$ & 0.01 & 0.007 & $<\mathrm{dl}$ & $<\mathrm{dl}$ & $<\mathrm{dl}$ & $<\mathrm{dl}$ & $<\mathrm{dl}$ & $<\mathrm{dl}$ & 0.47 & 0.135 & 0.04 & 0.007 & 3.27 & 1.289 \\
\hline
\end{tabular}


Table 1. Cont

\begin{tabular}{|c|c|c|c|c|c|c|c|c|c|c|c|c|c|c|c|c|c|c|}
\hline LD & $\mathrm{T} 18$ & S2 & 0.02 & 0.004 & 0.02 & 0.004 & $<\mathrm{dl}$ & $<\mathrm{dl}$ & $<\mathrm{dl}$ & $<\mathrm{dl}$ & $<\mathrm{dl}$ & $<\mathrm{dl}$ & 0.51 & 0.203 & 0.07 & 0.021 & 4.21 & 1.081 \\
\hline SL & T18 & S2 & 0.01 & 0.004 & 0.02 & 0.005 & 0.01 & 0.001 & $<\mathrm{dl}$ & $<\mathrm{dl}$ & $<\mathrm{dl}$ & $<\mathrm{dl}$ & 0.71 & 0.150 & 0.08 & 0.019 & 6.33 & 1.516 \\
\hline LD & T25 & S2 & 0.05 & 0.008 & 0.03 & 0.008 & 0.01 & 0.001 & 0.01 & 0.001 & 0.01 & 0.000 & 0.88 & 0.021 & 0.27 & 0.054 & 9.38 & 0.268 \\
\hline SL & $\mathrm{T} 25$ & S2 & 0.02 & 0.003 & 0.02 & 0.003 & 0.01 & 0.001 & $<\mathrm{dl}$ & $<\mathrm{dl}$ & $<\mathrm{dl}$ & $<\mathrm{dl}$ & 1.09 & 0.341 & 0.17 & 0.045 & 11.85 & 3.027 \\
\hline LD & $\mathrm{T} 10$ & S3 & $<\mathrm{dl}$ & $<\mathrm{dl}$ & $<\mathrm{dl}$ & $<\mathrm{dl}$ & $<\mathrm{dl}$ & $<\mathrm{dl}$ & $<\mathrm{dl}$ & $<\mathrm{dl}$ & $<\mathrm{dl}$ & $<\mathrm{dl}$ & 0.11 & 0.035 & 0.02 & 0.011 & 0.85 & 0.551 \\
\hline SL & $\mathrm{T} 10$ & S3 & $<\mathrm{dl}$ & $<\mathrm{dl}$ & $<\mathrm{dl}$ & $<\mathrm{dl}$ & $<\mathrm{dl}$ & $<\mathrm{dl}$ & $<\mathrm{dl}$ & $<\mathrm{dl}$ & $<\mathrm{dl}$ & $<\mathrm{dl}$ & 0.08 & 0.043 & 0.03 & 0.004 & 0.7 & 0.599 \\
\hline LD & T18 & S3 & $<\mathrm{dl}$ & $<\mathrm{dl}$ & 0.01 & 0.002 & $<\mathrm{dl}$ & $<\mathrm{dl}$ & $<\mathrm{dl}$ & $<\mathrm{dl}$ & $<\mathrm{dl}$ & $<\mathrm{dl}$ & 0.4 & 0.056 & 0.06 & 0.007 & 4.53 & 0.443 \\
\hline SL & $\mathrm{T} 18$ & S3 & $<\mathrm{dl}$ & $<\mathrm{dl}$ & 0.01 & 0.008 & 0.01 & 0.005 & $<\mathrm{dl}$ & $<\mathrm{dl}$ & $<\mathrm{dl}$ & $<\mathrm{dl}$ & 0.6 & 0.336 & 0.09 & 0.054 & 8.92 & 5.547 \\
\hline LD & T25 & S3 & $<\mathrm{dl}$ & $<\mathrm{dl}$ & 0.01 & 0.002 & 0.01 & 0.005 & $<\mathrm{dl}$ & $<\mathrm{dl}$ & $<\mathrm{dl}$ & $<\mathrm{dl}$ & 0.47 & 0.318 & 0.1 & 0.046 & 5.38 & 5.823 \\
\hline SL & $\mathrm{T} 25$ & S3 & $<\mathrm{dl}$ & $<\mathrm{dl}$ & 0.01 & 0.002 & 0.01 & 0.002 & $<\mathrm{dl}$ & $<\mathrm{dl}$ & $<\mathrm{dl}$ & $<\mathrm{dl}$ & 0.46 & 0.096 & 0.09 & 0.037 & 6.37 & 1.769 \\
\hline & & & \multicolumn{2}{|c|}{$18: 2 n-6$} & \multicolumn{2}{|c|}{$18: 3 n-3$} & \multicolumn{2}{|c|}{$20: 0$} & \multicolumn{2}{|c|}{$20: 1 n-9$} & \multicolumn{2}{|c|}{$20: 2 n-9$} & \multicolumn{2}{|c|}{$22: 0$} & & & & \\
\hline Host algae & Temperature & Salinity & mean & sd & mean & $\mathrm{sd}$ & mean & $\mathrm{sd}$ & mean & $\mathrm{sd}$ & mean & $\mathrm{sd}$ & mean & $\mathrm{sd}$ & & & & \\
\hline LD & $\mathrm{T} 10$ & S1 & 9.92 & 1.743 & 0.97 & 0.214 & 0.04 & 0.009 & 0.01 & 0.005 & 0.03 & 0.005 & 0.02 & 0.003 & & & & \\
\hline SL & $\mathrm{T} 10$ & S1 & 10.98 & 1.901 & 0.92 & 0.133 & 0.03 & 0.006 & 0.01 & 0.001 & 0.04 & 0.005 & 0.02 & 0.002 & & & & \\
\hline LD & $\mathrm{T} 18$ & S1 & 9.38 & 2.822 & 0.16 & 0.027 & 0.03 & 0.015 & 0.01 & 0.002 & 0.04 & 0.015 & 0.02 & 0.005 & & & & \\
\hline SL & $\mathrm{T} 18$ & S1 & 6.59 & 1.594 & 0.16 & 0.054 & 0.02 & 0.003 & 0.01 & 0.002 & 0.02 & 0.004 & 0.01 & 0.001 & & & & \\
\hline LD & $\mathrm{T} 25$ & S1 & 10.48 & 2.265 & 0.07 & 0.018 & 0.02 & 0.004 & 0.01 & 0.005 & 0.07 & 0.017 & 0.02 & 0.002 & & & & \\
\hline SL & $\mathrm{T} 25$ & S1 & 8.95 & 1.945 & 0.11 & 0.019 & 0.02 & 0.005 & 0.01 & 0.001 & 0.04 & 0.022 & 0.02 & 0.004 & & & & \\
\hline LD & $\mathrm{T} 10$ & S2 & 8.71 & 2.021 & 0.66 & 0.199 & 0.04 & 0.008 & 0.01 & 0.003 & 0.05 & 0.023 & 0.01 & 0.005 & & & & \\
\hline SL & $\mathrm{T} 10$ & S2 & 4.7 & 1.691 & 0.37 & 0.113 & 0.02 & 0.007 & 0.01 & 0.002 & 0.03 & 0.019 & 0.01 & 0.008 & & & & \\
\hline LD & $\mathrm{T} 18$ & S2 & 6.23 & 1.565 & 0.08 & 0.015 & 0.02 & 0.008 & $<\mathrm{dl}$ & 0.002 & 0.05 & 0.026 & 0.01 & 0.003 & & & & \\
\hline $\mathrm{SL}$ & $\mathrm{T} 18$ & S2 & 8.46 & 1.561 & 0.12 & 0.011 & 0.03 & 0.007 & 0.01 & 0.003 & 0.03 & 0.012 & 0.02 & 0.003 & & & & \\
\hline LD & T25 & S2 & 14.24 & 0.745 & 0.07 & 0.017 & 0.04 & 0.005 & 0.01 & 0.003 & 0.05 & 0.019 & 0.02 & 0.002 & & & & \\
\hline SL & $\mathrm{T} 25$ & S2 & 14.92 & 3.861 & 0.09 & 0.019 & 0.05 & 0.017 & 0.01 & 0.004 & 0.05 & 0.017 & 0.04 & 0.011 & & & & \\
\hline LD & $\mathrm{T} 10$ & S3 & 1.24 & 0.743 & 0.07 & 0.036 & $<\mathrm{dl}$ & $<\mathrm{dl}$ & $<\mathrm{dl}$ & $<\mathrm{dl}$ & 0.01 & 0.004 & $<\mathrm{dl}$ & $<\mathrm{dl}$ & & & & \\
\hline SL & $\mathrm{T} 10$ & S3 & 1.08 & 0.697 & 0.08 & 0.038 & $<\mathrm{dl}$ & $<\mathrm{dl}$ & $<\mathrm{dl}$ & $<\mathrm{dl}$ & $<\mathrm{dl}$ & $<\mathrm{dl}$ & $<\mathrm{dl}$ & $<\mathrm{dl}$ & & & & \\
\hline LD & $\mathrm{T} 18$ & S3 & 4.99 & 0.463 & 0.05 & 0.004 & 0.02 & 0.003 & 0.01 & 0.002 & 0.02 & 0.005 & 0.01 & 0.002 & & & & \\
\hline $\mathrm{SL}$ & $\mathrm{T} 18$ & S3 & 7.84 & 4.272 & 0.09 & 0.041 & 0.03 & 0.015 & 0.01 & 0.005 & 0.02 & 0.006 & 0.01 & 0.005 & & & & \\
\hline LD & T25 & S3 & 7.75 & 8.020 & 0.03 & 0.011 & 0.02 & 0.020 & 0.01 & 0.006 & 0.03 & 0.020 & 0.02 & 0.009 & & & & \\
\hline SL & $\mathrm{T} 25$ & S3 & 7.25 & 2.175 & 0.04 & 0.017 & 0.02 & 0.004 & 0.01 & 0.003 & 0.02 & 0.004 & 0.01 & 0.002 & & & & \\
\hline
\end{tabular}


Concentrations of the most abundant fatty acids were compared according to temperature and salinity treatments. Figure 1 shows the differences between temperatures for each of these fatty acids per salinity treatment and algal host. For both LD and SL temperature changes induced few modifications of fatty acids concentrations at 23.5 practical salinity units (PSU). Significant changes were observed only for minor fatty acids such as 16:1n-7 or 18:3n-3 whereas most compounds (including major P. salina ones) showed significant changes with temperature at 50 and 70 PSU.

a)

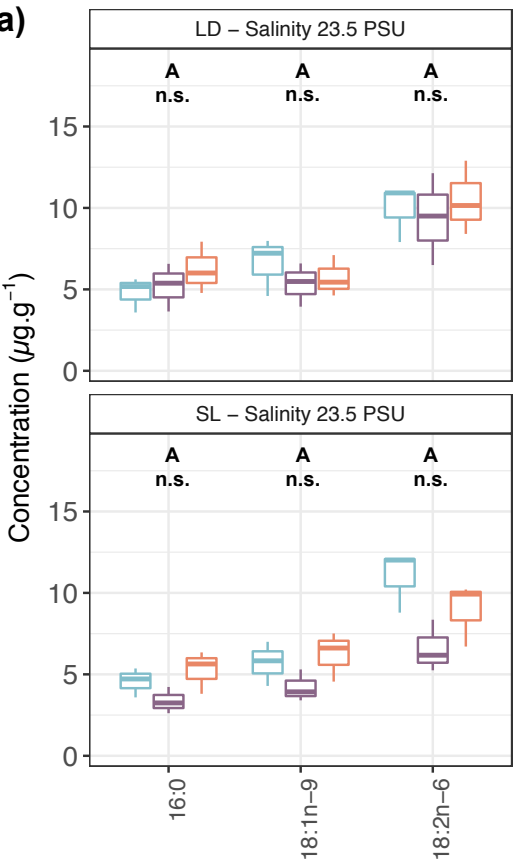

b)

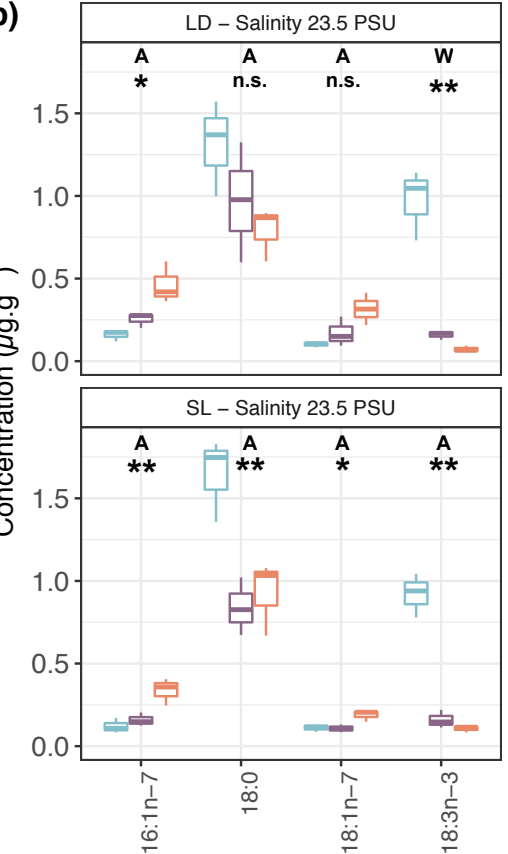

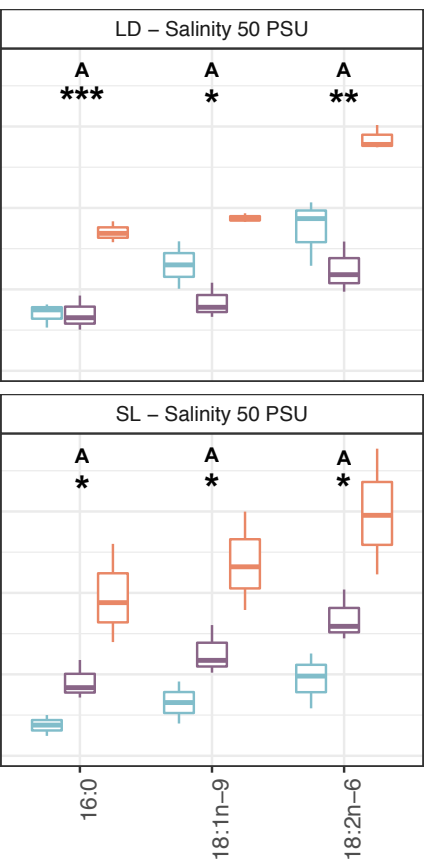
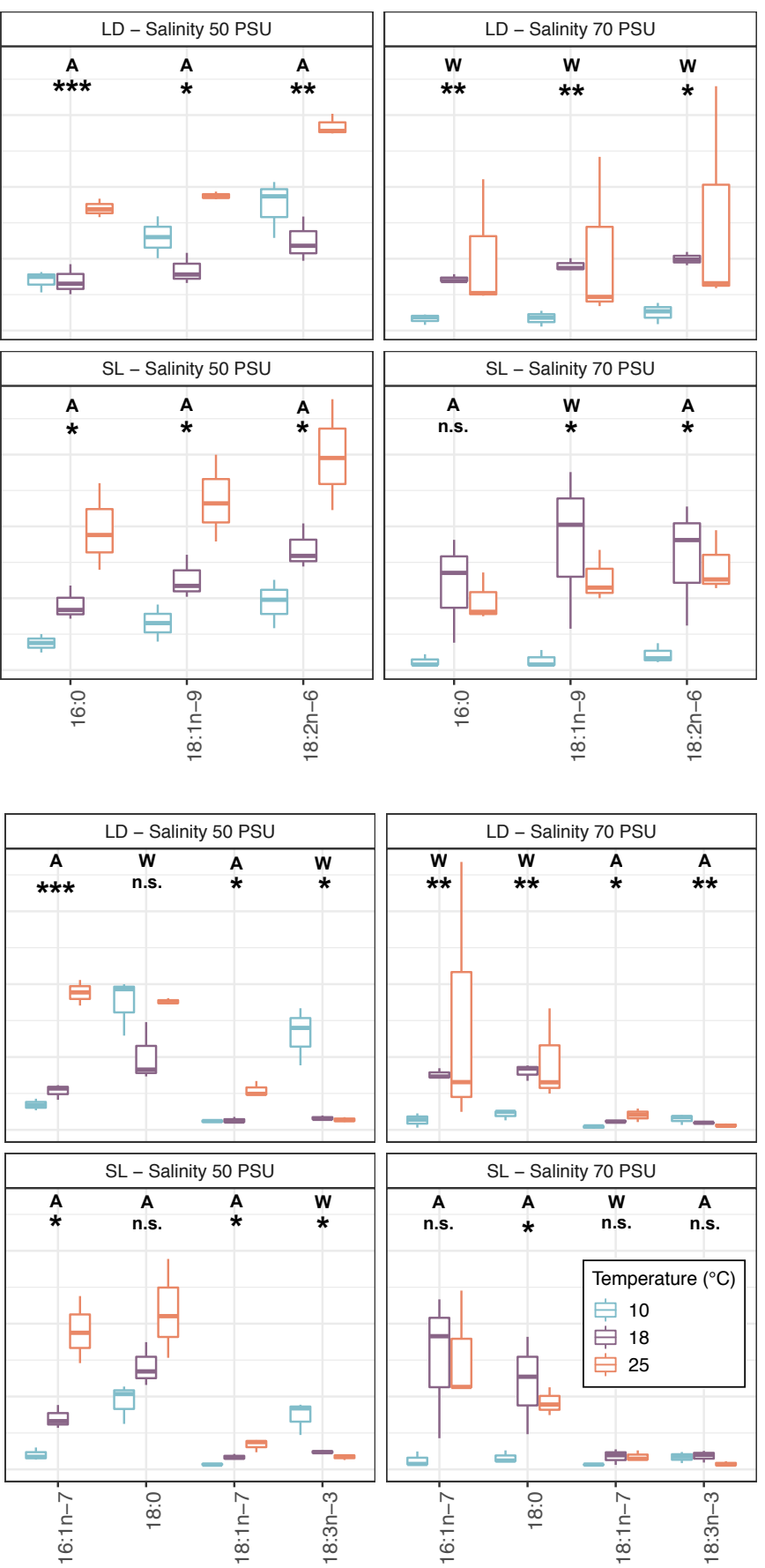

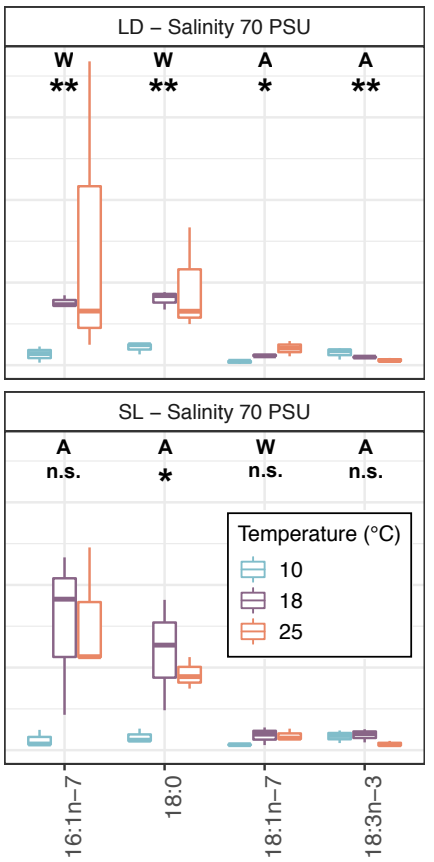

Figure 1. Concentrations ( $\mu \mathrm{g} \mathrm{g}^{-1}$ ) of the 7 most abundant fatty acids. (a) Higher concentrations and (b) lower concentrations of endophytic P. salina isolated from L. digitata (LD) or S. latissima (SL) and grown at different salinities (23.5, 50 and $70 \mathrm{PSU})$ and temperatures $\left(10,18\right.$ and $\left.25^{\circ} \mathrm{C}\right)$. One-way Welch ANOVA (W) or One-way ANOVA (A) has been performed depending on the result of Bartlett test: n.s. $=$ not significant, ${ }^{*} p<0.05,{ }^{* *} p<0.01$, and ${ }^{* *} p<0.001$. 


\subsection{Lipid Trajectories}

Principal Component Analyses (PCA) were performed using fatty acids relative proportions (in \%) for each salinity treatment (Figure $2 \mathrm{a}-\mathrm{c}$ ). The effect of the temperature gradient on fatty acids profiles is displayed for each salinity separately. The PCA allowed to track fatty acids trajectories which corresponded to the path of gradual change in whole fatty acid composition according to $\mathrm{T}^{\circ} \mathrm{C}$. At 70 PSU, no clear trajectories were observed and the PCA ordination explained $55 \%$ of the whole inertia in comparison to 61 and $63 \%$ for 23.5 and 50 PSU (Figure 2).

Lipid trajectories showed clear opposite directions at 23.5 and 50 PSU between host-algae (LD and SL) meaning that the elevation of temperature induced opposite responses in P. salina according to the algal host. Further investigation of lipid trajectories showed an opposition between 18:1n-9 and 18:2n-6. A fatty acid index $\left(F A I_{18-C}\right)$ was calculated using major $\mathrm{C} 18$ unsaturated fatty acids relative concentrations (\%) :

$$
F A I_{18-C}=\frac{[18: 2 n-6]}{[18: 1 n-9]}
$$

$F A I_{18-C}$ was significantly affected by host-algae, temperature and salinity effects (Table 2) but only host-algae:temperature and temperature:salinity interactions were significant.

Table 2. Thee-way analysis of variance (ANOVA) of $F A I_{18-C}$ index as a function of host-algae, temperature and salinity. Normality assumption by group was tested using Shapiro-Wilk. In total, 14 out of 18 groups showed $p>0.05$. Homogeneity of variance was tested using a Levene's test $\left(d f_{1}=17, d f_{2}=36\right.$, statistic $\left.=1.19, p=0.321\right)$. n.s. $=$ not significant, ${ }^{*} p<0.05$, and ${ }^{* * *} p<0.001$.

\begin{tabular}{ccccccc}
\hline & df & Sum of Square & Mean Squares & $\boldsymbol{F}$ & $\boldsymbol{p}$-Value & \\
\hline Host algae (host) & 1 & 0.1020 & 0.1020 & 5.661 & 0.022774 & $*$ \\
Temperature (temp) & 2 & 0.4321 & 0.2160 & 11.985 & 0.000102 & $* * *$ \\
Salinity (sal) & 2 & 1.2981 & 0.6491 & 36.009 & $2.57 \times 10^{-9}$ & $* * *$ \\
host:temp interaction & 2 & 0.8079 & 0.4040 & 22.411 & $4.76 \times 10^{-7}$ & $* * *$ \\
host:sal interaction & 2 & 0.0098 & 0.0049 & 0.272 & 0.763277 & n.s. \\
temp:sal interaction & 4 & 0.6356 & 0.1589 & 8.815 & $4.55 \times 10^{-5}$ & $* * *$ \\
host:temp:sal interaction & 4 & 0.0804 & 0.0201 & 1.115 & 0.364467 & n.s. \\
Residuals & 36 & 0.6489 & 0.0180 & & & \\
\hline
\end{tabular}

It also showed clear opposed linear relationships with temperature according to the algal host (Figure 2d). The index increased with temperature in LD but decreased in SL. At salinities 23.5 and 50 PSU the effect of host algae on $F A I_{18-C}$ was significant as the assumption of homogeneity of slope regression was not met (ANCOVA, interaction host-algae:temperature, $F=35.509, d f_{n}=1, d f_{d}=14$, $p=3.49 \times 10^{-5}$ and $F=34.483, d f_{n}=1, d f_{d}=14, p=4.06 \times 10^{-5}$ respectively). This indicated that slopes of the regression lines were significantly different. At the salinity of 70 PSU, the homogeneity of slope regression was validated (ANCOVA, interaction host-algae:temperature, $F=2.818, p=0.115$ ) but the effect of host algae was not significant (ANCOVA-temperature effect: $F=4.124, p=0.06$, host-algae effect: $F=0.355, p=0.56$ ). When regression lines were significantly different, the angle between the two regression lines was calculated (hereafter named $\alpha$-value). It represented the degree of influence of host-algae in the adaptation of P. salina to temperature (Figure 2). This degree of influence was significantly decreasing with salinity (Supplementary Materials Figure S1). 
a) PCA - Ind: Salinity 23.5 PSU
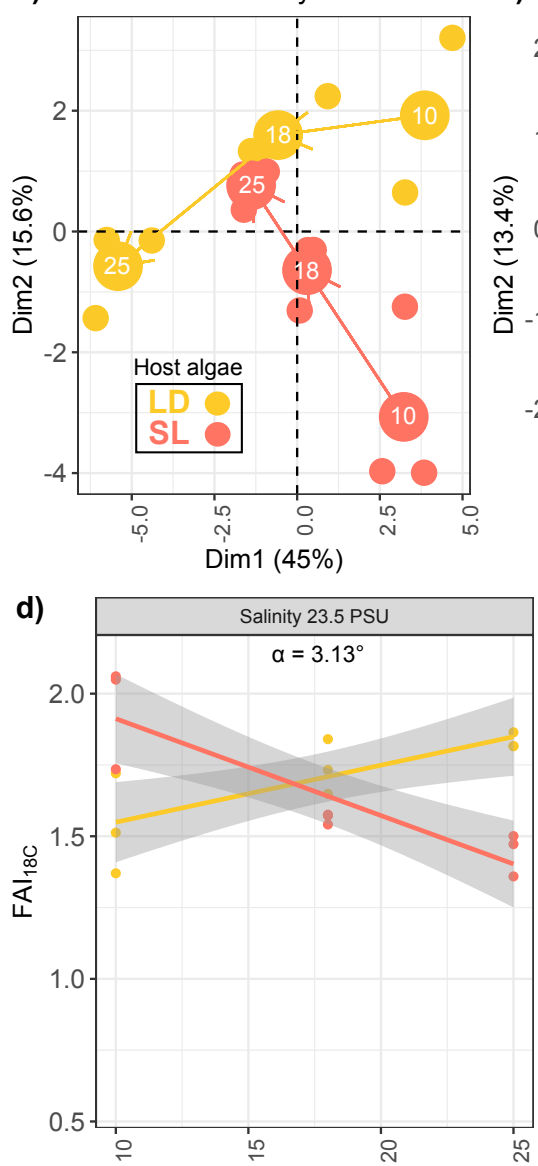

b) PCA - Ind: Salinity 50 PSU

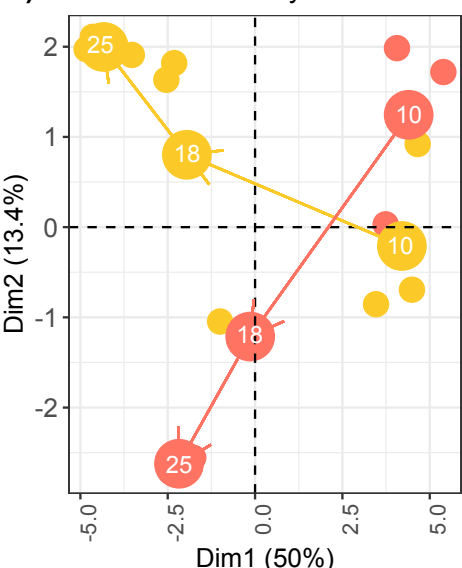

c) PCA - Ind: Salinity 70 PSU

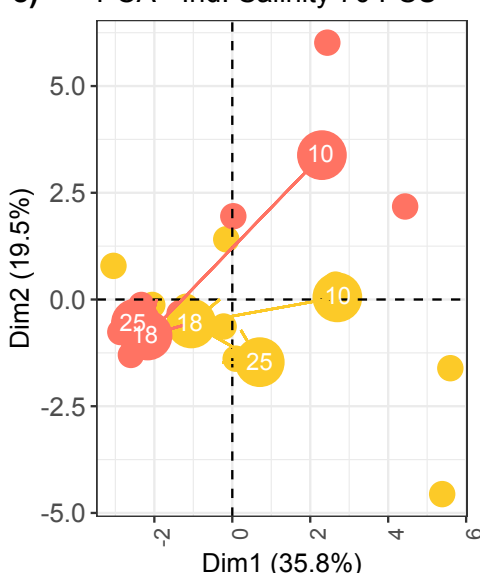

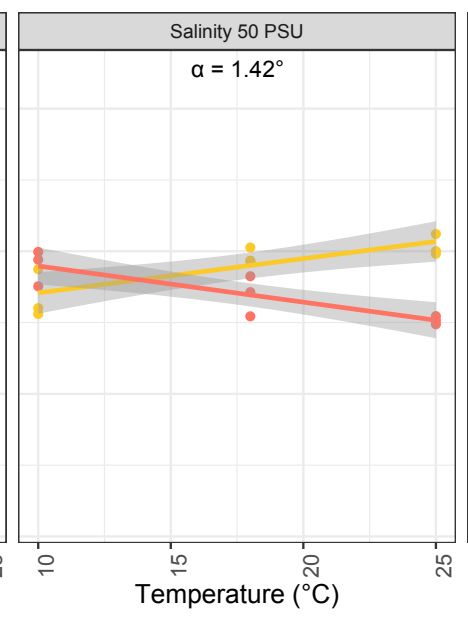

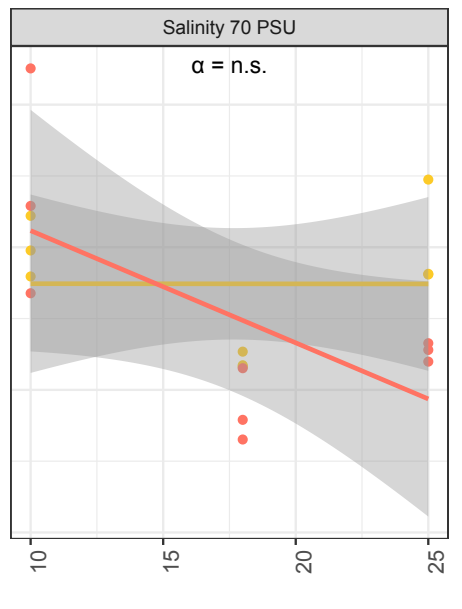

Figure 2. Fatty acid trajectories of endophytic P. arenaria isolated from L. digitata (LD) or S. latissima (SL) grown at different salinities (23.5, 50 and $70 \mathrm{PSU})$ and different temperatures $\left(10,18\right.$ and $\left.25^{\circ} \mathrm{C}\right)$ : (a-c) PCA scores. (d) $F A I_{18-C}$ index calculated with relative contributions (\%) of major C18 fatty acids showing opposite trends in the acclimation of $P$. salina to temperature between host algae. $\alpha=$ angle between the two regression lines.

\section{Discussion}

\subsection{Fatty Acid Compositions of P. salina in Relation to Experimental Conditions}

The cosmopolitan fungi $P$. salina is widely spread in all type of marine ecosystems, which clearly demonstrate its effective capacity to adapt to diverse temperature and salinity conditions $[5,6]$. In the present study, salinity levels (including the extreme 70 PSU) did not impact drastically total fatty acid concentrations, except a noticeable decrease at $10{ }^{\circ} \mathrm{C}$ and 70 PSU (Supplementary Materials Figure S2), which further illustrate the capacity of the fungi to thrive at salinity conditions well beyond the growth capacity of both host-algae.

Several studies have documented the effect of environmental variables on recruitment, survival, growth, size, biomass and density of kelps, nutrient and light being key factors [16,17]. Along the NE Atlantic (Norwegian) coasts, L. hyperborea abundance is, for instance, primarily driven by the interaction between wave exposure and either depth or ocean currents, implying depth-specific effects of wave exposure and wave-specific effects of current speed [18]. In terms of salinity tolerance, L. digitata exhibit optimal growth between salinity of 23 and 31 PSU, with a strong reduction of growth at 16 PSU and high mortality below 8 PSU [1]. In a study on Artic kelps, Karsten et al. [19] showed that, on a gradient from 5 to 60 PSU, maximum effective quantum yields (a proxy for photosynthetic efficiency) were measured between 20 and 55 PSU for L. digitata and S. latissima. Thus, in the present study, while 50 PSU 
is already a challenging condition; 70 PSU is clearly extreme for these species. Interestingly, despite the recognised phenotypic plasticity of $P$. salina and that the fungi was able to grow at the highest studied salinity without significant loss in total lipid mass, the observed fatty acids trajectories as well as $F A I_{18-C}$ relationships were no longer observed at 70 PSU. This indicated a dynamic relationship of the fatty acid metabolism between $P$. salina and its host-algae and is emphasized by the opposed response to temperature increase between both algal host species.

\subsection{Divergent Fatty Acid Trajectories in P. salina Revealed Adaptive Strategies to Temperature Changes}

Kelp forests are found on rocky seabeds from temperate to Arctic ecosystems and many species, such as Laminaria sp., have an important adaptive capacity to temperature changes [1]. For instance, endemic Arctic L. solidungula grow at temperatures between 5 and $16{ }^{\circ} \mathrm{C}$, and cold-temperate NE Pacific species grow between 0 and $18{ }^{\circ} \mathrm{C}$ with optima between 5 and $15^{\circ} \mathrm{C}$. The growth range of cold-temperate $\mathrm{N}$ Atlantic species extends from 0 to $20^{\circ} \mathrm{C}$ with optima between 5 and $15{ }^{\circ} \mathrm{C}$ while warm-temperate Atlantic species grow at up to $23-24{ }^{\circ} \mathrm{C}$ and have slightly elevated optima [1]. The temperature gradient investigated in the present study is thus within the range of natural temperature conditions.

When submitted to this gradient, endophytic $P$. salina showed divergent fatty acids trajectories as well as $F A I_{18-C}$ relationships depending on the host. At salinities 23.5 and 50 PSU the effect of host algae on $F A I_{18-C}$ was significant. The host effect was more pronounced at 23.5 than at 50 PSU as shown by the $\alpha$-value and disappeared at the extreme 70 PSU which indicated that the opposition in lipid metabolism and C18 trajectories between LD and SL are conserved throughout the salinity gradient although severe (50 PSU) and extreme (70 PSU) salinities did impact $P$. salina fatty acid metabolism.

In L. digitata C18 fatty acids and especially linoleic acid (18:2n-6) are essential in the response of the algae against stressful conditions such as the perception of pathogenic metabolites [20] or against grazing by specialised herbivorous species [21]. The response, in all cases, imply an oxidative stress and the activation of fatty acid oxidation cascades [22]. For instance, early events in the perception of pathogens lipopolysaccharides in this brown alga include the production of 13-hydroxyoctadecadienoic acid (13-HODE) as a result of the oxydation of 18:2n-6 by lipoxygenase activity [20]. A decrease in fatty acid occurs in S. latissima during the early development from gametes to gametophytes. The decrease was significant for $18: 1 \mathrm{n}-9$, from 45 to $30 \%$ of total fatty acids, suggesting that it might be important in the transition from storage lipids to photo-autotrophic strategies [23]. Thus, an increase in $F A I_{18-C}$ in laminariales is likely associated to the redirection of the algal lipid metabolism toward photosynthesis or defence to the detriment of storage lipids.

Homeoviscous and homeophasic adaptations, which is the process of keeping adequate membrane fluidity, as a response to temperature changes are well documented for microorganisms. Degree of unsaturation, variation in chain length, branching and cyclization of fatty acids are known adaptative strategies to enhance membrane fluidity. A considerable decrease in 18:1 and the marked increase in 18:2 or 18:3 with lower temperatures have already been observed in bacteria, fungus and yeast [24]. In the present study, any decrease in temperature is thus expected to induce an increase in $F A I_{18-C}$ as a response. However, this expected relationship was noticed only when the fungal endophyte was isolated from S. latissima and, intriguingly, it exhibited an opposite trend when isolated from L. digitata.

In absence of dedicated temperature experiments on both L. digitata and S. latissima, it is difficult to conclude on whether P. salina lipid metabolism was fully aligned with its host requirements. However, the observed opposed trend in lipid trajectories between the endophytic fungi of the two hosts revealed a temperature-response that was clearly host dependant.

Host species originated from separate areas (Roscoff-FR and Oban-UK for LD and SL respectively) which, despite being slightly warmer in average $(2.6 \pm 0.4)$ in Roscoff, are relatively similar in terms of sea surface temperature and salinity (SST NOAA). It is thus very likely that the two fungal strains originated from two different populations that were each adapted to their Laminariale host. 
Unfortunately, we do not have precise genomics information about the two endophytic strains (other than ITS barcode sequencing) to validate this hypothesis.

However, previous comparative metabolomics on the same endophytic strains, and seven additional $P$. salina isolates from various brown algae, have demonstrated a clearly divergent metabolome between algal species as well as orders (i.e., Fucales vs. Laminariales) [8]. Altogether, the present findings highlight the plasticity of the fungus to adapt to a new environment (i.e., the hosting algae). The fact that the host influenced the expression of $P$. salina metabolome may reflect epigenetic mechanisms as changes in metabolome expression [8] and lipid trajectories (this study) might be conserved across multiple generations.

\section{Materials and Methods}

\subsection{Reagents and Chemicals}

Following solvents were used: Sigma-Aldrich methanol $\geq 99.9 \%$ Cat No. 34860; ethanol $\geq 99.8 \%$ Cat No. 51976; chloroform $\geq 99 \%$ Cat No. C7559; hexane $\geq 99 \%$ Cat No. 139386. Following reagents were used for fatty acid purification and identification: BF3-methanol (boron-trifluoride methanol, Supelco ${ }^{\circledR}$, CAS Number: 373-57-9, Cat No. 15716) for derivatization; Sigma-Aldrich tricosanoic acid analytical standards (Sigma-Aldrich-C23-Methyl tricosanoate, CAS Number: 2433-97-8, Cat No. T9900) as internal standard; Supelco ${ }^{\circledR} 37$ Component FAME Mix, Cat No. CRM47885n, Marine source, Cat No. 47033, and Bacterial Mix, Cat No. 47080-U for fatty acid identification.

\subsection{Strain Isolation, Cultivation and Identification}

P. salina strains LD40H and SL540T were previously isolated from L. digitata (LD) and S. latissima (SL) respectively. Complete isolation, cultivation and molecular identification procedures are reported in Vallet et al. [2]. Briefly, three individuals of each species were collected during spring tide and processed within two hours of collection. Algae organs of $5 \mathrm{~cm}^{2}$ (receptacles, thalli, stipes, fronds and holdfasts) were excised and surface-sterilized by sequential immersion in Ethanol $70 \%$ (30 s), in $\mathrm{NaCl}$ $0.1 \%(30 \mathrm{~s})$ and washed three times $(30 \mathrm{~s})$ in sterilized sea water $[25,26]$. Algal segments were plated on solid media (malt extract agar, Millipore) with the internal tissues in contact with the medium and solidified with $20 \mathrm{~g} \cdot \mathrm{L}^{-1}$ of purified agar. Strains corresponded to $P$. salina, a strictly marine fungus identified with ITS sequencing from all brown algal species investigated [2].

\subsection{Experimental Design}

Fungal endophytic strains LD40H and SL540T were grown on solid medium Malt Extract Agar for 21 days with $12 \mathrm{~h}$ photo-period under both temperature and salinity stress conditions. Several salinity concentrations were tested ranging from low $\left([\mathrm{NaCl}]=23.5 \mathrm{~g} \cdot \mathrm{L}^{-1}\right)$, elevated $\left([\mathrm{NaCl}]=50 \mathrm{~g} \cdot \mathrm{L}^{-1}\right)$ to extreme conditions $\left([\mathrm{NaCl}]=70 \mathrm{~g} \cdot \mathrm{L}^{-1}\right)$. Three incubation temperatures were also tested within the growth range of natural LD and SL population in the temperate Atlantic ocean $\left(10^{\circ} \mathrm{C}, 18^{\circ} \mathrm{C}\right.$ and $\left.25^{\circ} \mathrm{C}\right)$. Experiments were conducted in biological triplicates.

\subsection{Fatty Acid Extraction}

Fatty acid (FA) analysis was performed following the modified method of Bligh and Dyer [27] as modified by $[28,29]$. Before extraction, an internal standard (23:0) was added to every sample for quantification purpose $\left(0.5 \mathrm{mg} \mathrm{mL}^{-1}\right)$. Lipids were extracted with a 20 min ultrasonication (sonication bath, $80 \mathrm{kHz}$, Fisherbrand ${ }^{\mathrm{TM}}$ ) in a mixture of distilled water, chloroform and methanol in ratio 1:1:2 (v:v:v, in $\mathrm{mL}$ ). Lipids were concentrated under $\mathrm{N}_{2}$ flux, and saponified, in order to separate FA, with a mixture of $\mathrm{NaOH}\left(2 \mathrm{~mol} \mathrm{~L}^{-1}\right)$ and methanol $(1: 2, \mathrm{v}: \mathrm{v}$, in $\mathrm{mL})$ at $90^{\circ} \mathrm{C}$ during $90 \mathrm{~min}$. Saponification was stopped with $500 \mu \mathrm{L}$ hydrochloric acid. Samples were then incubated with BF3-methanol at $90^{\circ} \mathrm{C}$ during $10 \mathrm{~min}$ to transform free fatty acids into fatty acids methyl esters (FAME), which were isolated and kept frozen in chloroform. Just before analysis, samples were dried under $\mathrm{N}_{2}$ flux and transferred 
to hexane. One $\mu \mathrm{L}$ of the mixture was injected in a gas chromatograph (GC, Varian CP-3800 equipped with flame ionization detector), which allowed separation and quantification of FAME. Separation was performed with a Supelco ${ }^{\circledR}$ OMEGAWAX 320 column $(30 \mathrm{~m} \times 0.32 \mathrm{~mm}$ i.d., $0.25 \mu \mathrm{m}$ film thickness) with He as carrier gas. The following temperature program was used: $60{ }^{\circ} \mathrm{C}$ for $1 \mathrm{~min}$, then raise to $150{ }^{\circ} \mathrm{C}$ at $40{ }^{\circ} \mathrm{C} \cdot \mathrm{min}^{-1}$ (held $3 \mathrm{~min}$ ), then raise to $240{ }^{\circ} \mathrm{C}$ at $3{ }^{\circ} \mathrm{C} \cdot \mathrm{min}^{-1}$ (held $7 \mathrm{~min}$ ) at $1 \mathrm{~mL} \mathrm{~min}^{-1}$. FAME Peaks were identified by comparison of the retention time with analytical standards. Additional identification of the samples was performed using a gas chromatograph coupled to mass spectrometer (GC-MS, Varian 450GC with Varian 220-MS). Compounds annotation was performed by comparing mass spectra with NIST 2017 library. Fatty acids were quantified using the FID detector and the internal standard (C23). Corresponding fatty acids are designated as $\mathrm{X}: Y n-Z$, where $\mathrm{X}$ is the number of carbons, $Y$ the number of double bonds and $Z$ the position of the ultimate double bond from the terminal methyl (see [30] for additional information about naming convention).

\subsection{Statistics}

All statistical analyses were performed using R version 3.5.3 [31] and packages reshape [32], ggplot2 [32], rstatix [33], ade4 [34], factoextra [35] and cowplot [36] for data processing and visualisation. Raw GC-FID text file data together with in-house $\mathrm{R}$ script for data processing, univariate and multivariate statistics as well as figures are available at github repository: https: //github.com/Hubas-prog/Paradendryphiella_traject.

\subsubsection{Univariate}

Comparisons in fatty acids concentrations were performed using Analysis of Variances (ANOVA) after prior verification of the normality of the residuals (Shapiro test) and equality of variance (Bartlett test). When Bartlett test indicated that homoscedasticity was not met, one-way Welch's ANOVA (for unequal variances) was performed otherwise, classical one-way ANOVA was used.

Analysis of covariance (ANCOVA) was performed to compare $F A I_{18-C}$ index between temperatures within each salinity treatments. Linearity was inspected visually and homogeneity of regression slopes was checked by testing the interaction between temperature and host-algae. Regression lines were considered different if slopes were different. When slopes were not significantly different, the ANCOVA was performed by checking the presence of outliers and by removing the interaction effect to adjust the ANCOVA model.

\subsubsection{Multivariate}

Lipid trajectories were calculated using Principal Component Analysis (PCA). PCA allowed to track fatty acids changes in relative proportion in the whole fatty acid profile rather than in a given compound. The aim was to check whether fatty acid trajectories were convergent, divergent or alike in response to temperature increase. Trajectories were studied by comparing PCA scores (i.e., individuals) between host-algae and within each salinity treatment. PCA loadings (i.e., variables) was inspected visually to detect which fatty acids were responsible for lipid trajectories. Univariate staticitics were then performed as described above to validate any changes.

Supplementary Materials: The following are available online at http:/ /www.mdpi.com/1660-3397/18/8/379/s1, Figure S1: $\alpha$ value as a function of salinity; Figure S2: Total fatty acid concentrations of $P$. salina.

Author Contributions: Conceptualization, S.P. and M.V.; Validation, C.H., T.M. and S.P.; Formal analysis, C.H.; Investigation, M.V., S.P., N.T.; Resources, M.V. and S.P.; Data curation, C.H.; Writing-original draft preparation, C.H.; Writing-review and editing, C.H., M.V., T.M., and S.P.; Visualization, C.H.; Supervision, S.P., C.H. and T.M.; Project administration, S.P. and C.H.; Funding acquisition, S.P. and C.H. All authors have read and agreed to the published version of the manuscript.

Funding: This research was funded by the French CNRS-INSU EC2CO program—project "ISLAY".

Acknowledgments: The authors thank the two anonymous reviewers for their constructive comments. 
Conflicts of Interest: The authors declare no conflict of interest. The funders had no role in the design of the study; in the collection, analyses, or interpretation of data; in the writing of the manuscript, or in the decision to publish the results.

\section{Abbreviations}

The following abbreviations are used in this manuscript:

$\begin{array}{ll}\text { LD } & \text { Laminaria digitata } \\ \text { MPB } & \text { Microphytobenthos } \\ \text { MUFA } & \text { Monounsaturated fatty acid } \\ \text { PUFA } & \text { Polyunsaturated fatty acid } \\ \text { QS } & \text { Quorum Sensing } \\ \text { SFA } & \text { Saturated fatty acid } \\ \text { SL } & \text { Saccharina latissima } \\ \text { TFA } & \text { Total Fatty Acids } \\ \text { PSU } & \text { practical salinity units } \\ \text { ANOVA } & \text { analysis of variance } \\ \text { PCA } & \text { principal component analyses } \\ \text { FAME } & \text { Fatty acid methyl esters } \\ \text { NIST } & \text { National Institute of Standards and Technology } \\ \text { FID } & \text { flame ionization detector }\end{array}$

\section{References}

1. Bartsch, I.; Wiencke, C.; Bischof, K.; Buchholz, C.M.; Buck, B.H.; Eggert, A.; Feuerpfeil, P.; Hanelt, D.; Jacobsen, S.; Karez, R.; et al. The genus Laminaria sensu lato: Recent insights and developments. Eur. J. Phycol. 2008, 43, 1-86. [CrossRef]

2. Vallet, M.; Strittmatter, M.; Murúa, P.; Lacoste, S.; Dupont, J.; Hubas, C.; Genta-Jouve, G.; Gachon, C.M.M.; Kim, G.H.; Prado, S. Chemically-Mediated Interactions Between Macroalgae, Their Fungal Endophytes, and Protistan Pathogens. Front. Microbiol. 2018, 9. [CrossRef] [PubMed]

3. Sutherland, G.K. Marine Fungi Imperfecti. New Phytol. 1916, 15, 35-48. [CrossRef]

4. Michaelis, K.C.; Gessner, R.V.; Romano, M.A. Population Genetics and Systematics of Marine Species of Dendryphiella. Mycologia 1987, 79, 514-518. [CrossRef]

5. Dela Cruz, T.E.; Wagner, S.; Schulz, B. Physiological responses of marine Dendryphiella species from different geographical locations. Mycol. Prog. 2006, 5, 108-119. [CrossRef]

6. Kireev, Y.V.; Konovalova, O.P.; Myuge, N.S.; Shnyreva, A.V.; Bubnova, E.N. Cultural properties and taxonomic position of Helminthosporium-like fungal isolates from the White Sea. Microbiology 2015, 84, 665-676. [CrossRef]

7. Tourneroche, A.; Lami, R.; Hubas, C.; Blanchet, E.; Vallet, M.; Escoubeyrou, K.; Paris, A.; Prado, S. Bacterial-Fungal Interactions in the Kelp Endomicrobiota Drive Autoinducer-2 Quorum Sensing. Front. Microbiol. 2019, 10, 1693. [CrossRef]

8. Vallet, M.; Chong, Y.M.; Tourneroche, A.; Genta-Jouve, G.; Hubas, C.; Lami, R.; Gachon, C.; Klochkova, T.; Chan, K.G.; Prado, S. Novel $\alpha$-hydroxy $\gamma$-butenolides of kelp endophytes disrupt bacterial cell-to-cell signaling. Front. Mar. Sci. 2020. [CrossRef]

9. Pilgaard, B.; Wilkens, C.; Herbst, F.A.; Vuillemin, M.; Rhein-Knudsen, N.; Meyer, A.S.; Lange, L. Proteomic enzyme analysis of the marine fungus Paradendryphiella salina reveals alginate lyase as a minimal adaptation strategy for brown algae degradation. Sci. Rep. 2019, 9, 1-13. [CrossRef]

10. Barbosa, M.; Fernandes, F.; Pereira, D.M.; Azevedo, I.C.; Sousa-Pinto, I.; Andrade, P.B.; Valentão, P. Fatty acid patterns of the kelps Saccharina latissima, Saccorhiza polyschides and Laminaria ochroleuca: Influence of changing environmental conditions. Arab. J. Chem. 2020, 13, 45-58. [CrossRef]

11. Dawczynski, C.; Schubert, R.; Jahreis, G. Amino acids, fatty acids, and dietary fibre in edible seaweed products. Food Chem. 2007, 103, 891-899. [CrossRef]

12. Weete, J.D. Fatty Acids. In Lipid Biochemistry of Fungi and Other Organisms; Springer: Boston, MA, USA, 1980; pp. 49-95. [CrossRef] 
13. Bärenstrauch, M.; Mann, S.; Jacquemin, C.; Bibi, S.; Sylla, O.K.; Baudouin, E.; Buisson, D.; Prado, S.; Kunz, C. Molecular crosstalk between the endophyte Paraconiothyrium variabile and the phytopathogen Fusarium oxysporum-Modulation of lipoxygenase activity and beauvericin production during the interaction. Fungal Genet. Biol. 2020, 139, 103383. [CrossRef] [PubMed]

14. Fischer, G.J.; Keller, N.P. Production of cross-kingdom oxylipins by pathogenic fungi: An update on their role in development and pathogenicity. J. Microbiol. 2016, 54, 254-264. [CrossRef] [PubMed]

15. Savchenko, T.V.; Zastrijnaja, O.M.; Klimov, V.V. Oxylipins and plant abiotic stress resistance. Biochemistry 2014, 79, 362-375. [CrossRef] [PubMed]

16. Hurd, C.L. Water motion, marine macroalgal physiology, and production. J. Phycol. 2000, 36, 453-472. [CrossRef]

17. Norton, T.; Mathieson, A.; Neushul, M. A Review of Some Aspects of Form and Function in Seaweeds. Bot. Mar. 1982, 25, 501-510. [CrossRef]

18. Bekkby, T.; Smit, C.; Gundersen, H.; Rinde, E.; Steen, H.; Tveiten, L.; Gitmark, J.K.; Fredriksen, S.; Albretsen, J.; Christie, H.C. The abundance of kelp is modified by the combined impact of depth, waves and currents. Front. Mar. Sci. 2019, 6. [CrossRef]

19. Karsten, U. Research note: Salinity tolerance of Arctic kelps from Spitsbergen. Phycol. Res. 2007, 55, $257-262$. [CrossRef]

20. Küpper, F.C.; Gaquerel, E.; Boneberg, E.M.; Morath, S.; Salaün, J.P.; Potin, P. Early events in the perception of lipopolysaccharides in the brown alga Laminaria digitata include an oxidative burst and activation of fatty acid oxidation cascades. J. Exp. Bot. 2006, 57, 1991-1999. [CrossRef]

21. Ritter, A.; Cabioch, L.; Brillet-Guéguen, L.; Corre, E.; Cosse, A.; Dartevelle, L.; Duruflé, H.; Fasshauer, C.; Goulitquer, S.; Thomas, F.; et al. Herbivore-induced chemical and molecular responses of the kelps Laminaria digitata and Lessonia spicata. PLoS ONE 2017, 12, e0173315. [CrossRef]

22. Küpper, F.C.; Gaquerel, E.; Cosse, A.; Adas, F.; Peters, A.F.; Müller, D.G.; Kloareg, B.; Salaün, J.P.; Potin, P. Free Fatty Acids and Methyl Jasmonate Trigger Defense Reactions in Laminaria digitata. Plant Cell Physiol. 2009, 50, 789-800. [CrossRef] [PubMed]

23. Steinhoff, F.S.; Graeve, M.; Wiencke, C.; Wulff, A.; Bischof, K. Lipid content and fatty acid consumption in zoospores/developing gametophytes of Saccharina latissima (Laminariales, Phaeophyceae) as potential precursors for secondary metabolites as phlorotannins. Polar Biol. 2011, 34, 1011-1018. [CrossRef]

24. Neidleman, S.L. Effects of temperature on lipid unsaturation. Biotechnol. Genet. Eng. Rev. 1987, 5, $245-268$. [CrossRef] [PubMed]

25. Kjer, J.; Debbab, A.; Aly, A.H.; Proksch, P. Methods for isolation of marine-derived endophytic fungi and their bioactive secondary products. Nat. Protoc. 2010, 5, 479-490. [CrossRef]

26. Kientz, B.; Thabard, M.; Cragg, S.M.; Pope, J.; Hellio, C. A new method for removing microflora from macroalgal surfaces: An important step for natural product discovery. Bot. Mar. 2011, 54, 457-469. [CrossRef]

27. Bligh, E.G.; Dyer, W.J. A Rapid Method of Total Lipid Extraction and Purification. Can. J. Biochem. Physiol. 1959, 37, 911-917. [CrossRef]

28. Meziane, T.; Tsuchiya, M. Fatty acids as tracers of organic matter in the sediment and food web of a mangrove/intertidal flat ecosystem, Okinawa, Japan. Mar. Ecol. Prog. Ser. 2000, 200, 49-57. [CrossRef]

29. Passarelli, C.; Meziane, T.; Thiney, N.; Boeuf, D.; Jesus, B.; Ruivo, M.; Jeanthon, C.; Hubas, C. Seasonal variations of the composition of microbial biofilms in sandy tidal flats: Focus of fatty acids, pigments and exopolymers. Estuarine Coast. Shelf Sci. 2015, 153, 29-37. [CrossRef]

30. Fahy, E.; Subramaniam, S.; Brown, H.A.; Glass, C.K.; Merrill, A.H.; Murphy, R.C.; Raetz, C.R.; Russell, D.W.; Seyama, Y.; Shaw, W.; et al. A comprehensive classification system for lipids. J. Lipid Res. 2005, 46, 839-861. [CrossRef]

31. R Core Team. R: A Language and Environment for Statistical Computing; R Foundation for Statistical Computing: Vienna, Austria, 2019.

32. Wickham, H. ggplot2: Elegant Graphics for Data Analysis; Springer: New York, NY, USA, 2016.

33. Kassambara, A. rstatix: Pipe-Friendly Framework for Basic Statistical Tests; 2020. Available online: https: / /CRAN.R-project.org / package=rstatix (accessed on 21 May 2020).

34. Dray, S.; Dufour, A.B. The ade4 Package: Implementing the Duality Diagram for Ecologists. J. Stat. Softw. 2007, 22, 1-20. [CrossRef] 
35. Kassambara, A.; Mundt, F. Factoextra: Extract and Visualize the Results of Multivariate Data Analyses; 2019. Available online: https: / CRAN.R-project.org/package=factoextra (accessed on 21 May 2020).

36. Wilke, C.O. cowplot: Streamlined Plot Theme and Plot Annotations for ggplot2; 2019. Available online: https: / /CRAN.R-project.org/package=cowplot (accessed on 21 May 2020). 